\title{
CURRENT STATE OF COMMUNAL SEWAGE TREATMENT IN THE REPUBLIC OF KAZAKHSTAN
}

\author{
Dariusz Andraka', Kairat Ospanov², Menlibai Myrzakhmetov ${ }^{2}$ \\ 1 Department of Environmental Engineering Systems, Bialystok University of Technology, Wiejska Str. 45E, 15-351 \\ Białystok, Poland, e-mail: d.andraka@pb.edu.pl \\ 2 Kazakh National Technical University, Satpayev Str. 22A, 050013 Almaty, Kazakhstan, e-mail: ospanovkairat@ \\ mail.ru
}

Received: 2015.09.21

Accepted: 2015.10.06

Published: 2015.11.10

\begin{abstract}
Protection of water environment from pollution is one of the major tasks in the contemporary world. Nowadays, in the Republic of Kazakhstan ecological situation concerning sewage treatment remains deficient. Raw sewage is often discharged directly onto filtration beds or landfills. Many existing wastewater treatment facilities in cities are in unsatisfactory technical conditions. In many villages and small settlement units the problem of treatment and disposal of sewage sludge from treatment facilities also requires urgent solutions. In this article, the current state of communal sewage treatment in the Republic of Kazakhstan is shown. The technical and technological characteristics of sewage disposal systems, including the cities of Almaty and Astana, are presented. This article is especially aimed at identification of environmental problems related with sewage treatment in the Republic of Kazakhstan.
\end{abstract}

Keywords: sewage treatment, sewage characteristics, decentralized systems, sustainability.

\section{INTRODUCTION}

The Republic of Kazakhstan is located between two continents - northwest of Asia and southeast of Europe. The state territory is 2724.9 thousand $\mathrm{km}^{2}$, making it the 9th largest country of the world. Kazakhstan is stretched between the delta of the Volga river in the west and Altai Mountains in the east, Western-Siberian lowland in the north and Tian-Shan mountains in the south. The extent of state frontiers makes nearly 13.4 thousand km, including: with Russian Federation - $7591 \mathrm{~km}$, Republic of Uzbekistan - 2354 km, Kirghiz Republic -1241 km, China -1782 $\mathrm{km}$, Turkmenistan $-426 \mathrm{~km}$.

According to statistical data, the population of Kazakhstan grows every year, reaching 17417.7 thousand persons at the beginning of 2015 (population density -6.4 persons $/ \mathrm{km}^{2}$ ). In the Republic there are 87 cities (among them 2 cities: Almaty and Astana are of republican im- portance), 30 villages and 6724 rural settlements which are administratively divided into 14 regions and 176 administrative districts [Committee on Statistics 2015].

544 sewage treatment facilities operate on the territory of the republic. The total extent of sewerage network has more than 14.5 thousand $\mathrm{km}$ of sewers, among them the main collectors make $4757.7 \mathrm{~km}$ and distribution network - $9773.6 \mathrm{~km}$ [Zhumartov 2010]. The centralized system of wastewater disposal is dominating on urban territories of the Republic of Kazakhstan, collecting $62 \%$ of total sewage production in the country, from which $84 \%$ belongs to large cities and $10 \%$ to villages. From the existing 87 municipal sewage treatment facilities one third is in unsatisfactory technical conditions. In 39 cities and villages treatment facilities are absent - untreated wastewater is discharged directly on ground filtration fields, or landfills. Another real danger is constituted by the sewage storing reservoirs located in 
surroundings of large settlements and industrial centers. In the Republic of Kazakhstan there are 540 sewage reservoirs, many of which are filled to a limiting level, creating threat for natural water resources and urban areas [Baekenova 2011]. Data on the largest sewage reservoirs of Kazakhstan are presented in Table 1.

From the Table 1 it can be observed that reservoirs in Kyzylorda, Kostanai, Petropavlovsk are filled to a designed level, which means that there is no extra volume available for accepting additional discharges. It should also be mentioned that almost all storages are in poor technical conditions due to lack of systematic geotechnical and hydro-chemical control. In the case of reservoir Sorbulak (storage for the city of Almaty - pos.1 in Table 1) in 1995 the by-pass channel was constructed to avoid overfilling the storage. This channel discharges cleaned sewage from Almaty treatment facilities to the Ili river in case of overflows [Zhumartov, Ospanov 1998].

In general, deficient ecological situation connected with inefficient operation of sewage treatment facilities remains in the Republic of Kazakhstan. In many cases it is caused by long-term exploitation without reconstruction of treatment facilities, other plants often lack technological objects required for a full mechanical and biological treatment. That situation contributes to the deterioration of environment due to discharges of inadequately treated wastewater. Recently, it became obvious that antropogenous eutrophication affected a significant part of surface and ground water resources in Kazakhstan. The results of environmental monitoring showed that for a few last years the concentration of nitrate nitrogen $\left(\mathrm{N}-\mathrm{NO}_{3}\right)$ in several rivers and lakes was exceed- ing the maximum approved limit by a factor of $1.1-3.7$ and ammonia nitrogen (N-NH3) - by 1.1 - 14.2 [Baekenova 2011]. In this regard, the "Ak Bulak" program on providing population with qualitative drinking water and wastewater disposal services for 2011-2020 was accepted by Kazakh Government [Ministry of Economic Development and Trade 2011].

\section{COMMUNAL SEWAGE DISPOSAL SYSTEMS IN SELECTED AREAS OF KAZAKHSTAN}

\section{Characteristics of wastewater and treatment methods in small cities and villages of Almaty region}

During the last decade the Department of Engineering Systems and Environment Protection of Kazakh National Technical University in Almaty conducted regular monitoring of sewage composition as well as technical conditions of treatment facilities in more than 30 settlements of the Republic of Kazakhstan with population ranging from 2000 to 150000 inhabitants, including the cities of Almaty and Astana. Table 2 presents the data collected from 15 small cities in Almaty region. It is worth noting that only 3 of the monitored cities had their own treatment facilities consisting of mechanical preliminary treatment and biological treatment in natural conditions using filtration beds before discharging to receiving waters.

Physicochemical characteristics of raw wastewater from small settlements in Almaty region, presented in Table 3, shows relatively low concentrations of both mineral and organic con-

Table 1. Technical parameters of the largest sewage reservoirs in Kazakhstan

\begin{tabular}{|c|c|c|c|c|}
\hline \multirow{2}{*}{ Location } & \multicolumn{2}{|c|}{ Capacity [mln m³] } & \multicolumn{2}{|c|}{ Fill level [m, above sea level] } \\
\hline & designed & actual & designed & actual \\
\hline Almaty & 1000 & 860 & 622.0 & 620.5 \\
\hline Astana & 63 & 44 & 347.2 & 346.2 \\
\hline Aktobe & 40.4 & 8 & - & - \\
\hline Atyrau & 16 & 8 & - & - \\
\hline Arkalyk & 68.7 & 38.5 & - & - \\
\hline Kyzylorda & 5 & 4.8 & - & - \\
\hline Kokshetau & 15 & 60 & 240 & 239.4 \\
\hline Kostanai & 97 & 101 & 184.8 & 184.2 \\
\hline Petropavlovsk & 35 & 35 & 102 & 102 \\
\hline Oral & 43.5 & 24.3 & 51.0 & 49.8 \\
\hline Shymkent & 25.8 & 11.4 & - & - \\
\hline
\end{tabular}


Table 2. Characteristics of sewage disposal systems in the Almaty region

\begin{tabular}{|l|c|c|c|l|}
\hline City & $\begin{array}{c}\text { Population } \\
{\left[10^{3} \mathrm{ppl}\right]}\end{array}$ & $\begin{array}{c}\text { Unit length of } \\
\text { main sewers } \\
{\left[\mathrm{km} / 10^{3} \mathrm{ppl}\right]}\end{array}$ & $\begin{array}{c}\text { Designed capacity } \\
\text { of treatment facilities } \\
{\left[10^{3} \mathrm{~m}^{3} / \mathrm{d}\right]}\end{array}$ & \multicolumn{1}{|c|}{ Method of sewage treatment } \\
\hline Kapchagai & 41.8 & 33.2 & 25.4 & Mechanical + filtration beds \\
\hline Talgar & 42.2 & 25.5 & 2.0 & Discharge to sewage disposal system of Almaty city \\
\hline Yesik & 25.9 & 23 & 4.2 & Mechanical + filtration beds \\
\hline Bakanas & 7.0 & 2.7 & 0.1 & Filtration fields \\
\hline Uzynagash & 22.2 & 1.0 & 1.0 & Mechanical + filtration beds \\
\hline Energeticheski & 17.5 & 26.2 & - & Discharge to sewage disposal system of Almaty city \\
\hline Burundai & 21.1 & 1.0 & 1.0 & Discharge to sewage disposal system of Almaty city \\
\hline Kaskelen & 30.7 & 48.4 & 0.1 & Discharge to sewage disposal system of Almaty city \\
\hline Kugaly & 4.9 & 0.8 & 0.2 & Filtration fields \\
\hline Chunzhaly & 18.5 & 7.0 & 1.6 & Mechanical + filtration beds \\
\hline Chilik & 24.4 & 13.3 & 5.2 & Mechanical + biological treatment \\
\hline Ushtobe & 22.3 & 1.0 & 1.0 & Discharge to treatment facilities of meat-processing \\
\hline Kirovskii & 12.6 & 0.4 & 0.2 & Discharge to treatment facilities of sugar factory \\
\hline Karabulak & 17.9 & 0.8 & 0.6 & Discharge to treatment facilities of sugar factory \\
\hline Zharkent & 34.5 & 22.0 & 7.0 & Mechanical + filtration beds \\
\hline
\end{tabular}

Table 3. Characteristics of raw wastewater from selected cities in Almaty region

\begin{tabular}{|l|c|c|c|c|}
\hline \multicolumn{1}{|c|}{ Indicator } & Shelek & Zharkent & Talgar & Bakanas \\
\hline Suspended solids $\left(\mathrm{mg} / \mathrm{dm}^{3}\right)$ & $58-102$ & $60-90$ & $80-90$ & $70-80$ \\
\hline $\mathrm{BOD}_{5}\left(\mathrm{mgO}_{2} / \mathrm{dm}^{3}\right)$ & $60-80$ & $70-90$ & $70-90$ & $50-70$ \\
\hline $\mathrm{COD}\left(\mathrm{mgO}_{2} / \mathrm{dm}^{3}\right)$ & $70-100$ & $80-100$ & $80-100$ & $60-80$ \\
\hline $\mathrm{pH}$ & $7.1-7.2$ & $7-7.1$ & $7-7.2$ & $7-7.5$ \\
\hline Dry solids $\left(\mathrm{mg} / \mathrm{dm}^{3}\right)$ & 120 & 160 & $130-150$ & - \\
\hline Ammonia nitrogen $\left(\mathrm{mg}^{2} / \mathrm{dm}^{3}\right)$ & $3.8-5$ & $3.8-12$ & $18-22$ & $5-8$ \\
\hline Nitrite nitrogen $\left(\mathrm{mg} / \mathrm{dm}^{3}\right)$ & $0.2-0.3$ & $0.2-0.3$ & $0.05-0.1$ & $0.2-0.3$ \\
\hline Nitrate nitrogen $\left(\mathrm{mg} / \mathrm{dm}^{3}\right)$ & $1.3-4$ & $2.3-5$ & - & $16-21$ \\
\hline Chlorides $\left(\mathrm{mg} / \mathrm{dm}^{3}\right)$ & $35-40$ & $1.5-20$ & $30-32.5$ & $1.5-2.0$ \\
\hline Sulfates $\left(\mathrm{mg} / \mathrm{dm}^{3}\right)$ & $60-70$ & $40-50$ & $60-75$ & $30-35$ \\
\hline Phosphates $\left(\mathrm{mg}^{3} / \mathrm{dm}^{3}\right)$ & $2-3$ & $2-4$ & $5-7$ & $2-4$ \\
\hline
\end{tabular}

taminants. Despite this fact, the discharge of inadequately treated sewage poses a serious treat for the environment - especially for ground waters, due to implementation of inefficient treatment methods, relying mostly on filtration beds.

\section{Sewage disposal systems in the main cities of Kazakhstan}

Almaty is the largest city of Kazakhstan known as "Southern Capital". According to the current demographic reports, population at the beginning of 2014 reached 1507509 people [Committee on Statistics 2014]. The climate of Almaty is classified as continental, with additional influence of mountain and valley circulation, which is especially shown in the northern part of the city located directly in a zone of transition from the mountains into the plain. Average air temperature is equal to $10^{\circ} \mathrm{C}$, with the coldest month (January) $-4.7^{\circ} \mathrm{C}$ and the warmest month (July) $23.8^{\circ} \mathrm{C}$.

The sewerage system of the Almaty city can be described as an incomplete separate system, consisting of storm sewers that collect rainfall waters and discharge them to small rivers and ditches, and municipal sewers network that collects industrial, commercial and household wastewater and transports it to Almaty Wastewater Treatment Plant (WWTP), popularly called "Stancia Aeracii" (aeration station) with designed capacity of $640.0 \mathrm{~m}^{3} /$ day.

Technological layout of the plant includes 3 stages: mechanical preliminary treatment, biological treatment using activated sludge bioreactors 
and discharge with conditioning in natural environment. Thanks to natural terrain configuration it is possible to transport wastewater between subsequent treatment units mostly by gravity. Technological interconnections and by-passes enable operation in several different modes (Figure 1).

The first stage of Almaty WWTP consists of 9 fine screens, followed by 8 horizontal grit chambers and 12 primary settling tanks (radial). After mechanical treatment, it is possible to discharge partially cleared wastewater to the emergency storage with the volume of $1500000 \mathrm{~m}^{3}$ and then to filtration beds with the area of 856 ha, located $12 \mathrm{~km}$ north of the plant.

Secondary treatment facilities are divided into 2 technological lines, including 2 types of aerated bioreactors (No. 1 - experimental; No. 2 - standard) with activated sludge and 12 final clarifiers (40 m radius) in total. Technical characteristic of bioreactors is given in Table 4. After biological treatment clarified wastewater is discharged either to natural reservoir Sorbulak or to the system of ditches and ponds called Right-bank Sorbulakski Channel (Pravobierezhnyj Sorbulakskij Kanal-PSK), where the tertiary treatment is accomplished. From PSK channel it is possible to discharge water to the Ili river, after disinfection using chlorine.

The physicochemical characteristic of sewage at different stages of treatment at Almaty WWTP is presented in Table 5 .

The second largest city in Kazakhstan and at the same time - the capital of the Republic is Astana, with the population of 814435 people at the beginning of 2014 [Committee on Statistics 2014]. The climate of Astana is extremely continental: with hot and dry summer, and very cold, long winter. Average annual temperature is $3.1{ }^{\circ} \mathrm{C}$. In the summer mean temperature is about $20{ }^{\circ} \mathrm{C}$ and in the winter $-15^{\circ} \mathrm{C}$, but it is not rare that in summer maximum temperature exceeds $40{ }^{\circ} \mathrm{C}$ (due to hot air masses from Central Asia) while in winter it drops below $-50{ }^{\circ} \mathrm{C}$ (due to Siberian frosts).

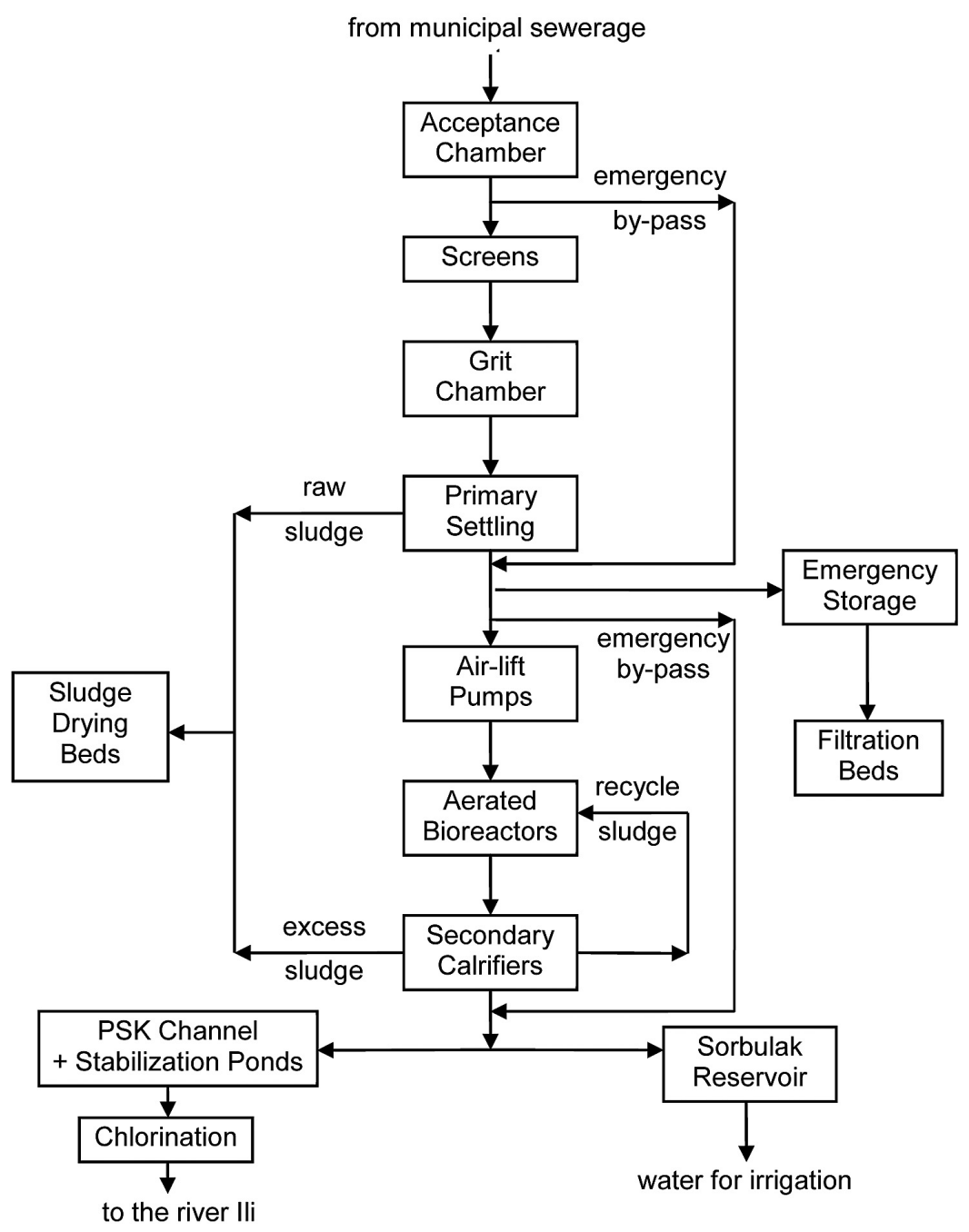

Figure 1. Technological diagram of Almaty WWTP [adapted from: Process ochistki 2015] 
Table 4. Technical characteristics of the bioreactors at Almaty WWTP

\begin{tabular}{|l|c|c|}
\hline \multicolumn{1}{|c|}{ Parameter } & Block 1 - experimental & Block 2 - standard \\
\hline Number of sections & $2(\mathrm{~A}+\mathrm{B})$ & 4 (No. 1, 2, 3, 4) \\
\hline Total volume & $\mathrm{V}=126280 \mathrm{~m}^{3}$ & $\mathrm{~V}=100000 \mathrm{~m}^{3}$ \\
\hline Dimensions (length $\mathrm{x}$ width) & $110 \times 164 \mathrm{~m}$ & $144 \times 144 \mathrm{~m}$ \\
\hline Dimensions of one section & $110 \times 80 \mathrm{~m}$ & $\mathrm{H}=5.0 \mathrm{~m}$ \\
\hline Operational depth & $\mathrm{H}=7.0 \mathrm{~m}$ & 4 \\
\hline Number of compartments in one section & 8 & $320000 \mathrm{~m}^{3} / \mathrm{day}$ \\
\hline Design capacity of the block & $320000 \mathrm{~m}^{3} / \mathrm{day}$ & \\
\hline
\end{tabular}

Table 5. Characteristics of a chemical composition of sewage at Almaty WWTP

\begin{tabular}{|c|c|c|c|c|}
\hline Indicator & $\begin{array}{l}\text { Raw sewage } \\
\text { (inflow) }\end{array}$ & $\begin{array}{l}\text { After mechanical } \\
\text { treatment }\end{array}$ & $\begin{array}{c}\text { After biological } \\
\text { treatment (discharge) }\end{array}$ & $\begin{array}{c}\text { Overall removal } \\
\text { efficiency (\%) }\end{array}$ \\
\hline Temperature $\left({ }^{\circ} \mathrm{C}\right)$ & 22.3 & 22.7 & 23.2 & - \\
\hline $\mathrm{pH}$ & 7.6 & 7.7 & 7.8 & - \\
\hline Suspended solids $\left(\mathrm{mg} / \mathrm{dm}^{3}\right)$ & 336.9 & 101.6 & 10.3 & 96.9 \\
\hline Dry mass $\left(\mathrm{mg} / \mathrm{dm}^{3}\right)$ & 655.3 & 494.0 & 435.8 & 33.5 \\
\hline Ammonia nitrogen $\left(\mathrm{mg} / \mathrm{dm}^{3}\right)$ & 32.7 & 24.3 & 4.3 & 86.9 \\
\hline Nitrites $\left(\mathrm{mg} / \mathrm{dm}^{3}\right)$ & 0.05 & 0.06 & 0.33 & - \\
\hline Nitrates $\left(\mathrm{mg} / \mathrm{dm}^{3}\right)$ & 0.13 & 0.19 & 8.17 & - \\
\hline $\mathrm{BOD}_{5}\left(\mathrm{mg} \mathrm{O}_{2} / \mathrm{dm}^{3}\right)$ & 409.1 & 84.6 & 10.1 & 97.5 \\
\hline $\mathrm{BOD}_{20}\left(\mathrm{mg} \mathrm{O}_{2} / \mathrm{dm}^{3}\right)$ & 575.7 & 93.9 & 14.4 & 97.5 \\
\hline $\operatorname{COD}\left(\mathrm{mg} \mathrm{O}_{2} / \mathrm{dm}^{3}\right)$ & 872.8 & 187.1 & 21.6 & 97.5 \\
\hline Detergents $\left(\mathrm{mg} / \mathrm{dm}^{3}\right)$ & 0.8 & 0.5 & 0.08 & 90.0 \\
\hline Phosphates $\left(\mathrm{mg} / \mathrm{dm}^{3}\right)$ & 8.9 & 7.2 & 3.1 & 65.2 \\
\hline Oil products $\left(\mathrm{mg} / \mathrm{dm}^{3}\right)$ & 2.66 & 0.98 & 0.004 & 99.5 \\
\hline Chlorides $\left(\mathrm{mg} / \mathrm{dm}^{3}\right)$ & 77.9 & 71.1 & 62.5 & 19.8 \\
\hline Sulfates $\left(\mathrm{mg} / \mathrm{dm}^{3}\right)$ & 71.5 & 67.6 & 62.5 & 12.6 \\
\hline Copper $\left(\mathrm{mg} / \mathrm{dm}^{3}\right)$ & 0.018 & 0.008 & 0.0006 & 96.7 \\
\hline Lead $\left(\mathrm{mg} / \mathrm{dm}^{3}\right)$ & 0.003 & 0.002 & 0.001 & 66.7 \\
\hline
\end{tabular}

Wastewater collected by municipal sewerage system of Astana is delivered by 2 pressure collectors of diameter 1500 and $2000 \mathrm{~mm}$ from main pumping station to wastewater treatment plant, which has an overall capacity of 136.000 $\mathrm{m}^{3} /$ day. The first technological stage of the plant is mechanical treatment which consists of fine screens, followed by 5 grit chambers and 6 radial primary settling tanks. The secondary biological treatment is accomplished in aerated bioreactors with activated sludge. Biological part of Alamty WWTP has 4 bioreactors, with dimensions (length $\times$ width $\times$ depth) $117 \times 32 \times 3,8 \mathrm{~m}$. Each reactor is divided into 4 compartments (width of $8 \mathrm{~m}$ ) and has $25 \%$ of its volume intended for regeneration of recycled activated sludge. The mixture of treated sewage and activated sludge goes to final clarifiers (10 units with a radius of $28 \mathrm{~m}$ each), where clear wastewater is separated from the sludge. The treated wastewater is then transported by pressure collectors from terminal pumping station to natural storage reservoir Taldy-Kol'. The characteristics of the treated wastewater in the Almaty WWTP is presented in Table 6.

\section{PERSPECTIVES FOR THE FUTURE}

"Ak Bulak" national program on developing water supply systems in the Republic of Kazakhstan assumed that in $2020-100 \%$ of the population in the cities (compared to $73 \%$ in 2010) and $80 \%$ of the population in rural areas $(41,2 \%$ in 2010) will be supplied with high quality water from centralized water supply systems [Ministry of Economic Development and Trade 2011]. Implementation of this goal means inevitable 
Table 6. Chemical composition of sewage at different stages of Astana WWTP

\begin{tabular}{|c|c|c|c|c|c|c|}
\hline \multirow{2}{*}{ Indicators } & \multicolumn{2}{|c|}{ Raw sewage (inflow) } & \multicolumn{2}{|c|}{ After mechanical treatment } & \multicolumn{2}{|c|}{$\begin{array}{l}\text { After biological treatment } \\
\text { (discharge) }\end{array}$} \\
\hline & $\min$ & $\max$ & $\min$ & $\max$ & $\min$ & $\max$ \\
\hline $\mathrm{pH}$ & 7.2 & 7.9 & 7.2 & 7.6 & 7.2 & 7.6 \\
\hline Temperature $\left({ }^{\circ} \mathrm{C}\right)$ & 9 & 22 & 18 & 22 & 18 & 23 \\
\hline $\mathrm{BOD}_{5}\left(\mathrm{mg} \mathrm{O}_{2} / \mathrm{dm}^{3}\right)$ & 105 & 270 & 70 & 105 & 3.0 & 15.0 \\
\hline $\operatorname{COD}\left(\mathrm{mg} \mathrm{O}_{2} / \mathrm{dm}^{3}\right)$ & 250 & 630 & 160 & 190 & 16.4 & 4.8 \\
\hline Suspended solids $\left(\mathrm{mg} / \mathrm{dm}^{3}\right)$ & 150 & 320 & 80 & 150 & 5.5 & 16.4 \\
\hline Phosphorus (mg/dm ${ }^{3}$ ) & 1.2 & 3.76 & 0.9 & 2.8 & 0.8 & 2.6 \\
\hline Dense rest $\left(\mathrm{mg} / \mathrm{dm}^{3}\right)$ & 1028 & 1472 & 525 & 686 & 325 & 436 \\
\hline Ammonia nitrogen $\left(\mathrm{mg} / \mathrm{dm}^{3}\right)$ & 15.0 & 37.0 & 10.8 & 27.0 & 5.4 & 7.8 \\
\hline Nitrates $\left(\mathrm{mg} / \mathrm{dm}^{3}\right)$ & 0.075 & 1.35 & 0.09 & 1.5 & 5.6 & 12.4 \\
\hline Nitrites $\left(\mathrm{mg} / \mathrm{dm}^{3}\right)$ & 0.03 & 0.17 & 0.03 & 0.19 & 0.1 & 0.8 \\
\hline Nickel $\left(\mathrm{mg} / \mathrm{dm}^{3}\right)$ & 0.11 & 0.24 & 0.05 & 0.2 & 0.001 & 0.003 \\
\hline Zinc $\left(\mathrm{mg} / \mathrm{dm}^{3}\right)$ & 0.05 & 0.55 & 0.01 & 0.4 & 0.001 & 0.01 \\
\hline Iron $\left(\mathrm{mg} / \mathrm{dm}^{3}\right)$ & 1.6 & 2.8 & 0.5 & 1.5 & 0.01 & 0.05 \\
\hline Oil products $\left(\mathrm{mg} / \mathrm{dm}^{3}\right)$ & 1.0 & 4.0 & 1.0 & 2.5 & 0.1 & 0.4 \\
\hline Detergents $\left(\mathrm{mg} / \mathrm{dm}^{3}\right)$ & 1.2 & 3.8 & 1.0 & 2.9 & 0.5 & 1.2 \\
\hline Sulfates $\left(\mathrm{mg} / \mathrm{dm}^{3}\right)$ & 211.0 & 328.0 & 180.0 & 250.0 & 60.0 & 150.0 \\
\hline
\end{tabular}

growth in water consumption, and at the same time - increasing production of wastewater. Taking into account the implementation of outdated technologies and poor technical conditions of the existing wastewater treatment facilities, it is necessary to undertake necessary steps to reconstruct and modify those objects or to build new treatment plants in justified cases. Special attention should be paid to the technologies with high efficiency of removing biogenic compounds.

One of possible and feasible solutions is modification of the existing activated sludge bioreactors by adding bio-film attachment surfaces (using different packing media), thus creating an integrated fixed-film activated sludge (IFAS) systems, which show a high potential for intensification of treatment process, especially in terms of removing nitrogen compounds [Randall and Seen 1996, Wang and Peng 2009]. In 2003, Scientific and Research Institute "WaterGeo" in Moscow (NII "VODGEO") prepared a technical report on "Technological recommendations on retrofitting Almaty WWTP", where the implementation of natural zeolite as a packing media was proposed for the reconstruction of the existing bioreactors. Re-designed bioreactor includes also anaerobic and anoxic zones that enhance biological phosphorus and nitrogen removal [Ospanov and Elzhasov 2010]. A schematic model of the proposed bioreactor is presented in Figure 2.
For a newly designed sewage disposal systems, both centralized and decentralized solutions may be considered, although decentralized systems are in general preferred for rural areas, while centralized ones - for urban settlements [Libralato et al. 2012, Gikas and Tchobanoglou 2009, Massoud et al. 2009]. Decentralized systems are gaining more and more attention, especially in developing countries, as they fit better to new expectations related with the concept of sustainable development. Technological solutions that can be used in decentralized systems can be divided as shown in Figure 3.

As described by Singhirunnusorn and Stenstrom [2009] appropriate solution of wastewater treatment system at a certain site should be selected taking into account various factors and variables presented in Figure 4.

Many authors emphasize that the most important factor in decision making process regarding water and wastewater management systems should be sustainability. It is worth noting that the term "sustainable technology" is very similar to "appropriate technology", which can be defined as a technology that is compatible with natural economic, technical and social environment and offers a possibility of further development. Assessing sustainability of wastewater treatment system can be supported by different techniques and tools, among them: exergy (ef- 


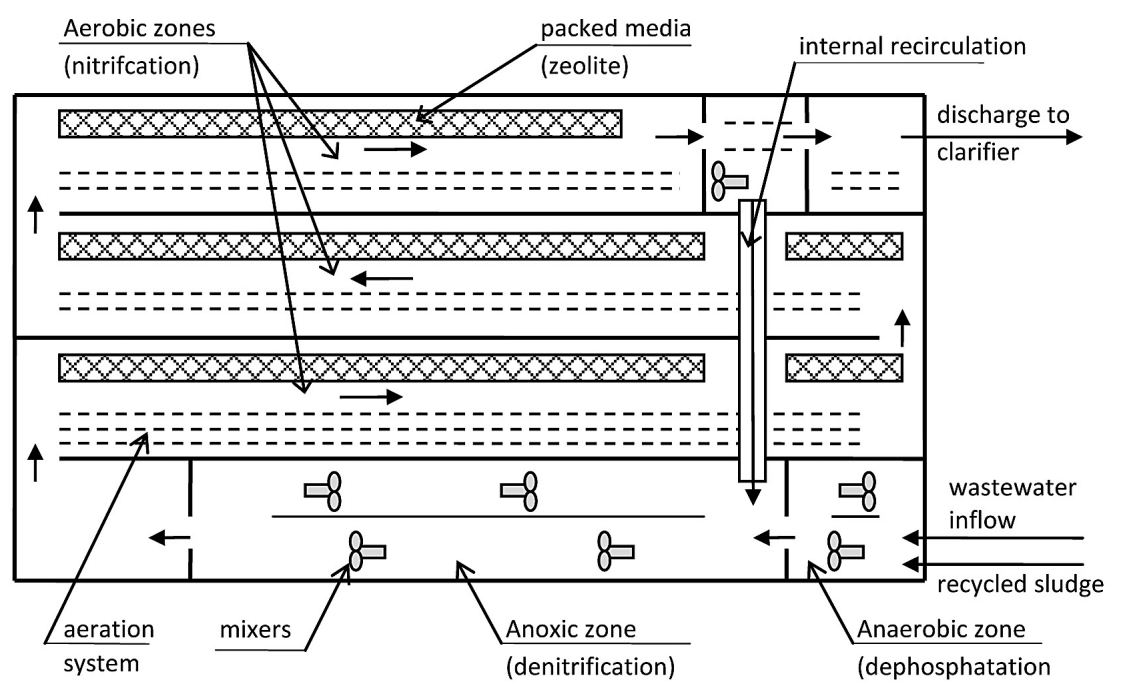

Figure 2. Proposal of IFAS system for Astana WWTP [adapted from Ospanov, Elzhasov 2010]

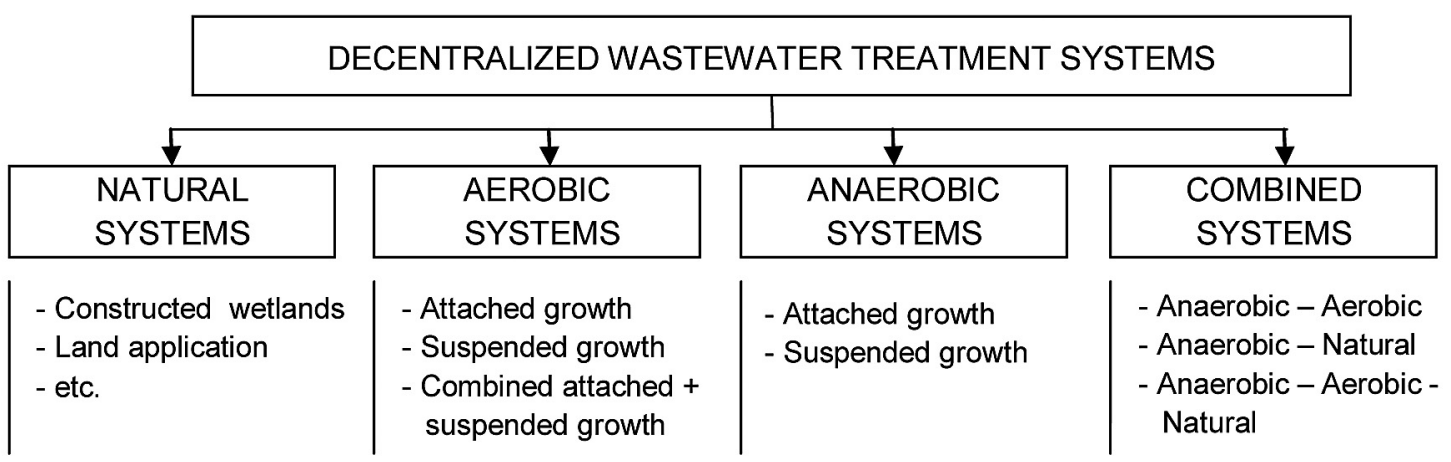

Figure 3. Classification of decentralized wastewater treatment methods [adapted from: Massoud et al. 2009]

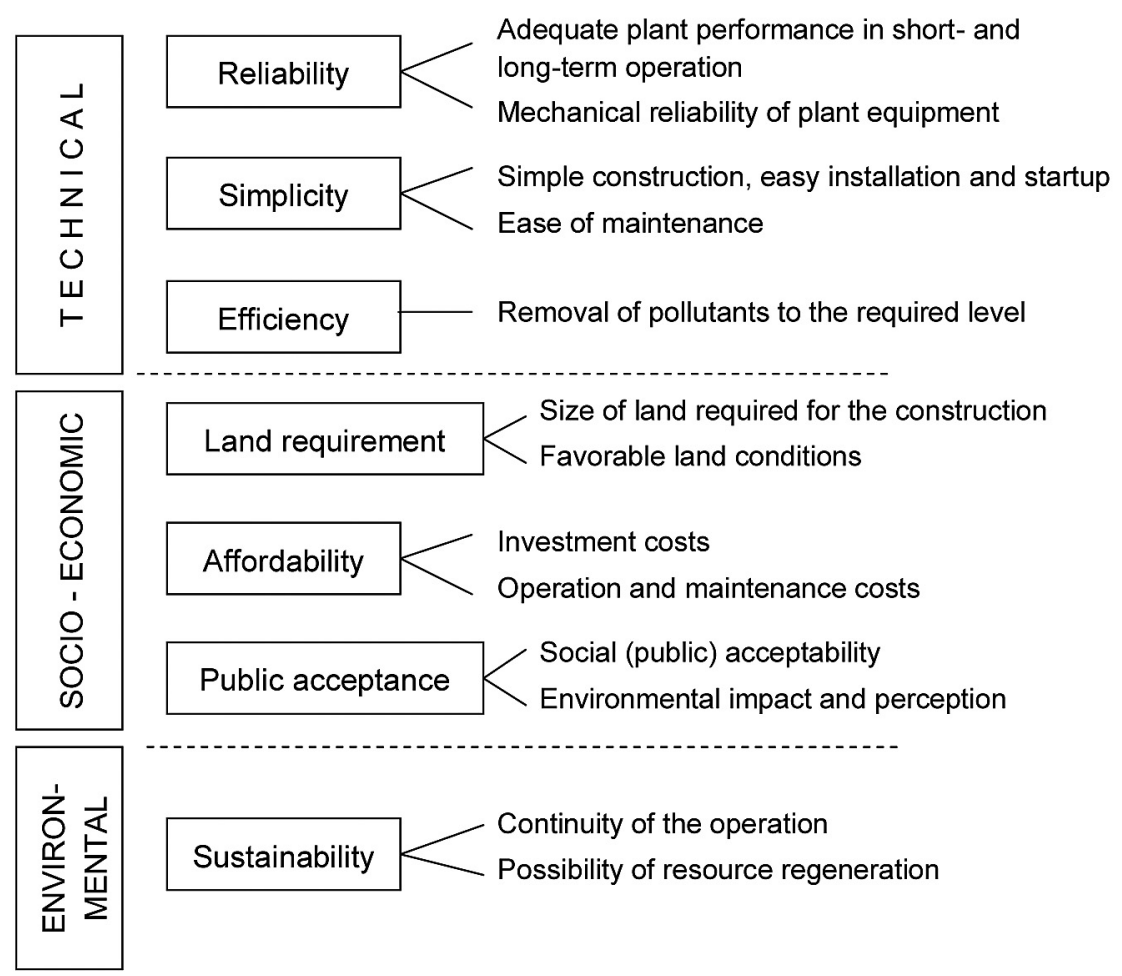

Figure 4. Conceptual variables determining selection of wastewater treatment technology [adapted from Singhirunnusorn and Stenstrom 2009] 
ficiency) analysis. economic analysis, life-cycle assesssement (LCA) and general system analysis are frequently used [Balkema et al. 2002]. All the above mentioned methods result in the estimation of specific indicators that make it possible to choose an optimum (i.e. most appropriate or sustainable) solution.

\section{CONCLUSIONS}

The general data obtained from monitoring small settlements in Kazakhstan show that wastewater from villages and small cities has relatively low content of mineral and organic pollutants, and very low salinity. At the same time most of those settlements are equipped with basic treatment facilities only (mechanical and natural treatment), which are old and often in poor technical conditions. Their construction and technological efficiency reflects the standards that were obligatory in the 1960-80's. These facts prove that ground and underground waters contamination that is observed recently in Kazakhstan has an anthropogenous origin and, in general, all settlements of the Republic of Kazakhstan contribute to deterioration of quality of underground waters. The most widespread and dangerous is pollution from nitrogen compounds.

The analysis of sewage disposal systems in main cities of Kazakhstan - Almaty and Astana shows good conditions of wastewater treatment facilities and their high efficiency in removal of organic and mineral compounds, represented by BOD and suspended solids respectively. For Almaty WWTP average efficiency of $\mathrm{BOD}_{5}$ removal is $97,5 \%$ and for suspended solids - $96,9 \%$, which results in high quality effluent with $\mathrm{BOD}_{5}$ concentration much lower than required $15 \mathrm{mg} /$ $\mathrm{dm}^{3}$. On the other hand, the efficiency of biogenic compounds removal still remains unsatisfactory, reaching only $30-40 \%$. To cope with this problem, the possibility of intensification of nitrogen and phosphorus removal using zeolite as bio-film carrier in activated sludge tank is being examined.

Undergoing rapid growth in centralized water supply of both urban and rural areas of Kazakhstan will also require a development of new sewage disposal systems or rebuilding the existing ones. In this regard, decentralized systems should be considered in particular, due to their better fit to sustainability concept and proved applicability in developing countries.

\section{REFERENCES}

1. Baekenova M.K. (Ed.) 2011. Nacional'nyj doklad o sostojanii okruzhajushhej sredy v Respublike Kazahstan v 2010 godu (Republic of Kazakhstan State of Environment 2011. National Report), Kazakh Research Institute for Ecology and Climate of the Ministry of Environment Protection of the Republic of Kazakhstan, Almaty, p. 241

2. Balkema A.J., Preisig H.A., Otterpohl R., Lambert F.J.D, 2002. Indicators for the sustainability assessment of wastewater treatment systems, Urban Water, 4, 153-161.

3. Committee on Statistics 2014. Dynamics of population (in .xlsx format), Ministry of National Economy of the Republic of Kazakhstan, Available from: http://www.stat.gov.kz/ (accessed 26 October 20140.

4. Committee on Statistics 2015. Kazakhstan in figures (in .pdf format), Ministry of National Economy of the Republic of Kazakhstan, Available from: http:// www.stat.gov.kz/ (accessed 30 August 2015).

5. Gikas, P., Tchobanoglous, G., 2009. The role of satellite and decentralized strategies in water resources management, Journal of Environmental Management, 90, 144-152.

6. Libralato G., Volpi Ghirardini A., Avezzu F. 2012. To centralize or to decentralize: An overview of the most recent trends in wastewater treatment management, Journal of Environmental Management, 94 , pp. $61-68$

7. Massoud, M.A., Tarhini, A., Nasr, J.A., 2009. Decentralized approaches to wastewater treatment and management: applicability in developing countries. Journal of Environmental Management, $90,652-659$.

8. Ministry of Economic Development and Trade 2011. Programma „AK Bulak” po obespecheniju naselenija kachestvennoj pit'evoj vodoj i uslugami vodootvedenija na 2011-2020 gody ("AK Bulak" Programme on providing the population with high quality water supply and sewage disposal services for 2011-2020) 2011, Ministry of Economic Development and Trade of the Republic of Kazakhstan, Available from: http://adilet.zan.kz/rus/docs/ P1100000570 (accessed 6 August 2014) .

9. Ospanov K.T. and Elzhasov A.A. 2010. Ochistnye sooruzhenija kanalizacii g.Astana (Kazahstan) (Sewerage Treatment Facilities of the City of Astana (Kazakhstan)), Vodosnabzhenie i Sanitarnaja Tekhnika (Water Supply and Sanitary Technique) No. 12 (2010), Available from: http://www.vstmag. ru/en/archives-all/2010/2010-12/974-ochistnyjesooruzhenija (accessed 18 July 2015).

10. Process ochistki 2015. Available from: http://astospasu.kz/?page_id=240 (accessed 4 Sept. 2015). 
11. Randall C.W. and Sen, D. 1996. Full-Scale Investigation of an Integrated Fixed-Film Activated Sludge (IFAS) Process for Enhanced Nitrogen Removal, Water Sci. Technol., 33 (12), 155-162.

12. Singhirunnusorn W. and Stenstrom M. K. 2009. Appropriate wastewater treatment systems for developing countries: criteria and indictor assessment in Thailand, Water Sci. Technol. 59(9), 1873-1884.

13. Wang S. and Peng Y. 2009. Natural zeolites as effective adsorbents in water and wastewater treatment. Chemical Engineering Journal, 156, 11-24.

14. Zhumartov E.B. 2010. Sovremennoje sostojanie vodosnabzhenija i kanalizacii naselennyh mest Respubliki Kazahstana (Current state of water supply and sewage disposak in the occupied places of the Republic of Kazakhstan), VODA: tekhnologija i ekologija (WATER: Technology and ecology), St. Petersburg, No. 3.

15. Zhumartov E.B. and Ospanov K.T. 1998. Sostojanie ochistki stochnyh vod malonasielennyh punktov Kazakhstana (Condition of sewage treatment of low populated areas of Kazakhstan), Sovershenstvovane inzhinernyh sistem i problemy ekologii, Mezhvuzovskij sbornik nauchnyh trudov, KazGASA, Almaty, 103-109. 